\title{
MIGRATION IN ANDREA LEVY'S SHORT NARRATIVES ${ }^{1}$
}

\author{
ANDREA LEVY'NINN KISA ANLATILARINDA GÖÇ
}

\section{Ayça VURMAY}

Dr. Öğr. Üye, Hatay Mustafa Kemal Üniversitesi, Fen-Edebiyat Fakültesi, Ingiliz Dili ve Edebiyatı Anabilim Dalt, aycavurmay@mku.edu.tr

10.33537/sobild.2020.11.1.11

\section{Makale Bilgisi}

Gönderildiği tarih: Kabul edildiği tarih: Yayinlanma tarihi:

31-10-2019 14-01-2020 31.01.2020

\section{Article Info}

Date submitted: Date accepted:

Date published:
31-10-2019

14-01-2020

31.01 .2020

\section{Keywords}

Andrea Levy, migration, colonialism, slavery, identity

\section{Anahtar sözcükler}

Andrea Levy, göç, sömürgecilik, kölelik, kimlik

\begin{abstract}
This paper aims to investigate the migrant experience in Levy's "Back to My Own Country: An Essay" and her short stories "The Diary" and "That Polite Way That English People Have". Levy's stories of migration blend fact with fiction, where autobiography, history, social commentary and fiction commingle. The stories manifest certain rewarding as well as negative aspects of migration in that they depict the migrant's desire to attain a fairy-tale world as well as the ironies of the migrant experience. In her narratives, Levy writes not only about her personal story as a second-generation migrant, her Jamaican as well as black-British heritage, her identity conflict, racial awareness and racism, and gender bias, but she also gives information and her opinions on slavery, colonialism, the Caribbean migrants of the Windrush generation and the intermingled history of Britain and the Caribbean. Levy's works can also be regarded as a rewriting of history as she aims to uncover the lost history shared by the Caribbean and Britain, and remedy the amnesia. Levy's use of the motif of "reverse migration" in her narratives helps her achieve this aim, as she moves the story of the Caribbean British from the margin to the centre, as a compensation for the past.
\end{abstract}

\section{$\ddot{O} z$}

Bu makalenin amacr göçmenin öyküsünü Levy'nin "Back to My Own Country: An Essay" (Ülkeme Dönüș: Bir Deneme)'inde ve "The Diary" (Günlük) ve "That Polite Way That English People Have" (İngilizler'in Sahip Olduğu O Malum Kibar Tavır) başlıklı öyküleri odağında incelemektir. Levy'nin öyküleri otobiyografi, tarih, toplumsal eleştiri ve kurmacayı kaynaştırmaktadır. Göç olgusunun bazı olumlu yönlerinin yani sira olumsuz yanlarinin da ortaya koyulduğu bu öykülerde göçmenin düşlediği peri masalıvari dünyanın yanında göçmen deneyiminin içerdiği ironiler göz önüne serilir. Söz konusu anlatılarda Levy, Karayipler'den Ingiltere'ye göç eden ikinci-kuşak göçmen olarak kendi öyküsünü, Jamaica'lı ve siyahi-Britanya'lı kültürel mirasını, yaşadiğ kimlik bunalımını ve ırksal farkındalık, ırkçılık, ve cinsiyetçi önyargılar ele alırken Atlantik köle ticareti, sömürgecilik ve Britanya İmparatorluğu, Karayipler'den göç eden Windrush kuşağ ve Britanya ve Karayiplerin ortak tarihi hakkındaki düşüncelerini ve bilgileri de sunmaktadır. Levy'nin amacinın hem kişisel mirasinı ve Karayipler'le Britanya'nın ortak mirasını açığa çıkarmak hem de tarihsel "unutkanliğ" bir derman olarak yapitlarinda tarihi yeniden yazmak olduğu söylenebilir. Yazarn "tersine göç" motifini kullanması bu amacın gerçekleștirmektedir. Nitekim, Britanya'lı Karayiplilerin öyküsünü marjinden merkeze taşıması, bir nevi geçmişin telafisi olarak görülebilir.

\footnotetext{
${ }^{1}$ This article is the extended and revised version of my paper entitled "Autobiography, History and Narrative: Migration in Andrea Levy's Six Stories and an Essay", presented at "The International Conference on Culture, Society and Literature: Migration and Changing Identities" at Atilim University, in November 2019.
} 


\section{Introduction}

Andrea Levy (1956-2019), in her latest book, entitled Six Stories and an Essay (2014), incorporates her autobiographical essay and her short stories belonging to different periods in her career, and explores the migrant condition as well as the intermingled histories of Britain and Jamaica. The story of the migrant in her book involves not only the migration of the Jamaicans to Britain, or "mother country", but also connects with the history of post/colonialism, imperialism and post/slavery. Levy's stories mainly deal with the reverse migration in the present, as her characters move from the Caribbean to England which is the opposite of migration to Caribbean which dominated history. Through the use of reverse migration, Levy compensates for historical amnesia, thereby foregrounding the repressed stories of the migrant, the Caribbean in particular.

In Six Stories and an Essay, Levy conveys the migrant story, history, and biography. The narrative aspect of the stories emphasizes the making of the history of multicultural Britain, fabricated by both black and white agents, thereby stressing their collective history or story. Levy's autobiographical essay "Back to My Own Country: An Essay" and the subsequent six stories share equal personal, social/historical and fictional or narrative aspects, as it is difficult to separate fact from fiction, and the personal from the social/historical. Levy narrates not only the post/colonial and migrant experience invented in history, but she also provides her own narrative or (re)writing of the history of Britain, of black British history as well as the migrant reality mainly through the view of the black British. Her memoir might represent the repressed, hidden, unconscious aspects of the history of postcolonial, multicultural Britain, which contains the dark memories of slavery and colonialism. Levy's use of the diary image signifies the shared memory of the black as well as the white British, which signifies their twin sibling. Her first-person narrative juxtaposes the intimacy, familiarity and integrality of personal story with the uncanniness and aloofness of history, exposing the ambivalence or hybridity of the memoir, its simultaneous alterity and familiarity, both personally and historically.

In an interview with Susan Alice Fischer, Levy expresses the amnesia in Britain about slavery and the need to confront it to redefine Britishness. Levy considers the British nation to be forgetful about the history of slavery and the slave-trade, which she argues, should be acknowledged to define national identity, as the history of Britain is merged with that of the Empire and the neglected experience of slavery. Levy explains her fiction as an attempt to relocate and rewrite the black history and writing, granting their centrality. Levy argues that the historical perception and image of Britain has ignored the black experience, which she aims to revive through her fiction, mainly through her characters who "stole the scene" (Levy and Fischer, 2014 , p. 134) from the white figures on the British stage of history, culture and literature:
When I was researching The Long Song and learning about the history of slavery and putting it against what I had learned in school and putting it against what I know of slavery in this country, I was thinking that this really needs to be brought centre stage. This is an incredibly important event that happened. I say event -300 years, if you can call that an event - and there's enormous amnesia about it in this country. We understand about abolition very well, but there's enormous amnesia about the preceding 300 years or more. This is very important to who we are as a nation, and it's very important to understand it. (Levy and Fischer, 2014, p.134)

Comparing her work with other contemporary British literary works, Levy maintains that her fiction "is serious work", which she emphasizes, is "more serious than a lot of serious writing in Britain" (Levy and Fischer, 2014, p. 131). She says that her struggle to fit in British society as a migrant is similar to her strife to challenge the white hegemony in British literature, as she challenges the supremacy of the white British culture like other Black British writers: "I'm hoping we're going to look back on it as a sort of Harlem Renaissance. [...] we're going to have to fight our way into the canon. I'll have to fight to get in the canon" (Levy and Fischer, 2014, p. 131). Levy also argues for the imperative for contemporary novelists writing about modern Britain to be informed of the multiple identities and heterogeneous cultures making Britain (Levy and Fischer, 2014, p.132). To Jeannette Baxter and David James, "Levy's insistence on the transnational and transcultural dimensions of British literature clearly explodes previous attempts at canon formation" (Baxter and James, 2014, p. 2). Humour is a central aspect of Levy's fiction, which is also instrumental in the struggle of her characters. Humour serves a palliative function in struggles with the adversities in life such as the challenges of migration as well as it makes it easier for the reader to acknowledge and confront multicultural experiences. Humour, Levy states, helps to "make the best of" your condition and to develop empathy about the condition of others as well as of yourself by making us "acknowledge the real humanity in people" (Levy and Fischer, 2014, p. 137).

Corinne Duboin underscores Levy's continuous interest in "the theme of identity formation complicated by gender and racial biases, the problematic construction of individual and collective selves among the African Diaspora", in her fiction, in order to "confront" global as well as British Eurocentrism (Duboin, 2011, p. 14). Duboin argues that the strained relationship between "liminality" and "insularity" at cultural, narrative and national levels determines Levy's writing as well as her outlook on migrancy (Duboin, 2011, p. 16).

Elif Öztabak Avc1 states that Levy's use of the figure of the refugee is "a new marker of the limits of tolerance and belonging in contemporary British society" (Öztabak Avc1, 2018, p. 354). Investigating Levy's short story "Loose Change", Öztabak Avc1 argues the text highlights 
the connections between national identity and the "historically variable and relational limits of tolerance and belonging", as well as portraying "contemporary representations of refugees, asylum seekers, and illegal immigrants in ways that are not unlike the representations of the colonized as well as black people in colonialist and racist discourses" (Öztabak Avc1, 2018, p. 365).

\section{Theoretical Framework: The Migrant}

Andrea Levy shares with Stuart Hall and Paul Gilroy the notion of the migrant experience as a fluid, contingent and intercultural phenomenon, which is connected with changing identities. Gilroy uses the image of the slave ship (Gilroy, 1993, p. 17), to account for the changing spaces as well as the changing identities of the black British and the metaphor of the sea of "the black Atlantic" to emphasize the crossing of national, racial, cultural and linguistic borders, as well as hybridity, and multiculturalism (Gilroy, 1993, p. ix 40). The dual aspect of the migrant experience can also be explained through Stuart Hall's concept of "familiar stranger" which concerns the conception of the black British migrant by the white British as an outsider to her own history and to the mother country. In other words, the migrant is the familiar Other or estranged foster brother or sister.

As Stuart Hall argues, "The history of migration can't be comprehended without the imperial connection" (Hall, 2018, p. 177). To Hall, Caribbean migration to England in the 1940s and 1950s was "the world turning inside out" (Hall, 2018, p. 173), as it "reversed" the colonial movement, through its movement from the peripheries of the colony to the centre (Hall, 2018, p.176). In other words, the Caribbean migration was like an atonement for the colonial past and an opportunity for the dispossessed Caribbean to fulfil their dreams. However, the diasporic experience involved "incongruities", "illusions" and unavoidable "difference". The master-slave relationship concerning colonizer and colonized, the British and the Jamaican and the inequality in power and wealth separated the migrants who came to Britain as colonials, from the British. Hall views "the absent centre" of the colony, which has been the determining influence on colonial life has led Jamaicans to emigrate to the mother country. The journey from the Caribbean to England is the third and the final stage of the forced emigration which involves the return back to the centre of the empire as well as the return of all back "home". The triangular trade route involves the journey of British traders to Africa, the subsequent transference of the enslaved to the Caribbean and finally the transmission of the goods manufactured by the "forced labour" of the enslaved back to England, which Hall considers history's "turning back against itself" (Hall, 2018, pp. 174-177). Caribbean migration chiefly caused a "migrant crisis" (Hall, 2018, p. 183), as the Windrush migrants signified permanent residence of blacks in Britain which horrified the white British (Hall, 2018, p. 182), for whom, the coming of the black migrants posed a threat of being contaminated, dehumanized and "dispossessed", in Hall's words, "of being reduced to the state of the colonized" (Hall, 2018, p. 182). After the war, the black colonials who volunteered on the British front, led to a dilemma in the British identity, due to racial concerns. Racial fears including loss of the white identity due to mixing with non-white migrants had a great impact on the white English psyche. Racial and cultural prejudices brought about antagonism and conflicts between whites and blacks. The British conception of the black migrants was shaped by racial and cultural differences and stereotypes. To Stuart Hall, the white Britons' reaction to the black migrants can be explained as "historical forgetfulness", since the memory of the long history the British shared with the Caribbean was forgotten by the British (Hall, 2018, p. 185).

David Ellis states that in the decade following the Windrush immigration, which began "with the docking of the SS Empire Windrush in 1948 with 492 returning exservice personnel from the Caribbean" (Ellis, 2001, p. 215), Britain went through a transformation process, "shifting its national identity" from a global to a local level, bringing about not only the foundation of multicultural Britain but also of "a much broader process of reassessment", which is continuing at present (Ellis, 2001, p. 230). Ellis mentions the problems faced in the period such as accommodation and employment as "the British government had no policies to support its aim to integrate the migrants into the local community and economy" (Ellis, 2001, p. 216). He further notes that the period also saw the beginning of the endorsement of British racism, which was officially established through the enactment of The Commonwealth Immigrations Act in 1962 (Ellis, 2001, p. 217).

The Caribbean diaspora in Britain was established through the "unparalleled" migration of West Indians to Britain in the aftermath of the war to attain better positions in Britain which needed the migrants' labour, and to support the "mother country" in the "postwar recovery and restoration effort" however the migrants were shocked by the exclusion from Britishness (Evelyn, 2013, p. 130). Kim Evelyn argues that the colonial migrants in the post-World War II Britain were empowered as they were endowed with "refuge from" and "resistance to" racism through domesticity (Evelyn, 2013 , p. 131). Evelyn further states Andrea Levy's "migrant characters" treat domestic spaces and "homemaking" as a means of "autonomy" and "security" (Evelyn, 2013, p. 131).

Language is a primary means of expression for the migrants as they define their identity and culture through their use of language. Cynthia James maintains that "language is the main battleground on which British and West Indian cultures and identities clash and make accommodations" following the Windrush immigration to the Mother Country, as it is depicted in Andrea Levy's Small Island (James, 2010, p.46). James notes that besides the linguistic markers of cultural difference, both the West Indians and the British will need to grasp the language of the other as the novel's conclusion suggests (James, 2010, p.61). James further argues that parody functions as one of the chief ways in which the conflict between the two cultures are displayed (James, 2010, p.46). 


\section{The Migrant Experience in "Back to My Own} Country: An Essay"

In "Back to My Own Country: An Essay", Levy examines her experience as the daughter of Jamaican migrants and also the black experience in its historical connection with Britain. The essay begins with one of Levy's memories regarding her journey on a London bus as a young girl in the early 1960s, fifty years before. The memory mainly concerns the lack of communication and racial as well as cultural prejudice between the black and the white British, the Jamaican and the English, the migrant and the resident. Levy narrates the estrangement of the one black man, the Caribbean, on the bus due to the white majority English residents' attitude. Levy mentions the man's good manners and friendly attitude to the white British on the bus, which contrasts with the indifference of the latter. Levy expresses her mixed reaction to the man in that she was not only embarrassed by him but she also pitied him and even identified with him, as she noticed he was Caribbean like her family. Levy's ambivalent attitude to the Caribbean man also embodies the dualities and complications regarding the migrant experience. Levy thinks the misunderstanding between the man and the white Londoners resulted from racial and cultural difference, that is, the colour and the accent of the man. However, she was particularly astonished at the ignorance of the white British about one of the old colonies of Britain: "He looked different and he sounded different. But how come people in England did not know him? Why was he, and why were all black people from Britain's old empire, so completely alien to them?" (Levy, 2014, p. 2).

The anecdote about the black man on the London bus is crucial to Levy's aim as it is connected with her idea of forgetfulness on the part of the British about their black British and Caribbean history. The encounter with the man connects not only with Levy's unawareness of her black British and Jamaican heritage and history as well as the "lost history" of the Caribbean British for both the white and the black British, which Levy thinks, form the "silences" and "gaps" in the British memory and knowledge in the present, and which also brought about some "problems" for Levy:

But still there are silences and gaps in our knowledge and understanding. What are the links that made Britain a natural destination for that Caribbean man on the bus, fifty years ago? How and why did Britain forge those links in the first place? These are questions that have come to fascinate me, because they reveal what amounts to a lost history for many of us. It was certainly lost to me for much of my early life, and it was a loss that caused me some problems. (Levy, 2014, p. 2)

Andrea Levy can be regarded as a "familiar stranger" in terms of her relationship with her British and Caribbean heritage. Levy explains her identity crisis, her unawareness of her black heritage and the change in her attitude to her Jamaican and black heritage from embarrassment to pride. Her confrontation with her own hybridity and her identity crisis dates back to the period after graduating from the art college with a degree in textile design and beginning to work as a part-time instructor for a sex-education project for young people. Levy participated in a racism awareness course, which initiated her conflict with her identity, as it divided the black and the white into two groups, where she chose the white as she felt herself at home there however she painfully and with reservation realized that she had to join the black people due to her colour (Levy, 2014, p. 6). For her, "It was a life-changing moment", as she recognized that "I was not part of the black experience, surely?" and states that she was "scared to call" herself "a black person" (Levy, 2014, p. 6). She felt as an "imposter" (Levy, 2014, p. 6) with regard to her black identity, as she did not have a sense of belonging in the black culture.

For Levy, writing is a means of investigating her own heritage and identity as well as the black experience. The writing course she attended in London was an opportunity for her to make sense of her "upbringing and background" and her "complicated relationship with colour", which also enabled her to understand the meaning of being black (Levy, 2014, p. 8):

\begin{abstract}
I soon came to realise that my experience of growing up in this country was part of what it meant to be black. All those agonies over skin shade. Those silences about where we had come from. The shame. The denial. In fact I came to see that every black person's life, no matter what it is, is part of the black experience. Because being black in a majority white country comes with a myriad of complications and contradictions. It was writing that helped me to understand that. (Levy, 2014, p. 8)
\end{abstract}

Levy's visit to Jamaica in 1996 for the first time in her life, during her writing course, had a profound effect on her recognition of her heritage: "I realized for the first time that I had a background and an ancestry that was fascinating and worth exploring" (Levy, 2014, p. 9). The Caribbean heritage "is a very rich seam for a writer" says Levy and adds that it is "the reason that I write" (Levy, 2014, p. 9). Levy also alludes to Toni Morrison to demonstrate her view of the condition of being a black woman writer as a richness rather than a limitation (Levy, 2014, p. 9).

For Levy, the search for personal history becomes a journey into social history. In other words, Levy's personal story merges into the shared story of Britain and the Caribbean. Levy writes, "The more I began to delve into my Caribbean heritage the more interesting Britain's Caribbean story became for me. The story of the Caribbean is a white story too and one that goes back a long way" (Levy, 2014, p. 9). To Levy, the Windrush immigration has been highly rewarding for the British, which she thinks provided a "windfall of talent and variety" (Levy, 2014, p. 15). However, Levy also mentions the disillusionment, complications and 
difficulties it caused. She states the immigrants "belonged, whether Britain realised it or not" (Levy, 2014, p. 14). In her account of her parents' migration to England, Levy provides both personal and social historical information. The ironies of the migrant experience can be seen in the contrast between the expectations and desires of Levy's parents and their disillusionment, problems and failure in England. Being migrants, for Levy, determined not only the Levies' life but it has considerably transformed Britain. The Windrush migrants were social outcasts in England. The ironic gap between the hopes of the migrant and the indifference of the residents is manifest in Levy's mother's mistaking the fireworks on the day she came to England for a celebration of their arrival.

But my parents had come to this country from Jamaica. And in the area of London where we lived, that made my family very odd. We were immigrants. Outsiders. My dad had been a passenger on the Empire Windrush ship when it famously sailed into Tilbury in June 1948 and, according to many, changed the face of Britain for ever. My mum came to England on a Jamaica Banana Producer's boat. It sailed into West India dock on Guy Fawkes Night in the same year, under a shower of fireworks that my mum believed were to welcome her. (Levy, 2014, p. 3)

The adversities of migration are reflected in the Levies' case as social deprivation, loss of social status, loss of place, loss of language, unemployment, lack of opportunity, poverty, homelessness, and bad housing conditions (Levy, 2014, p. 3). Levy narrates her parents' disillusionment in England, being deprived of their middle class life in Jamaica, which involved "large houses", "servants" and good careers (Levy, 2014, p. 3). Levy's mother, for instance, could not work as a teacher in England as her qualifications received in Jamaica were not accepted. However, she still cherished the dream of becoming a teacher (Levy, 2014, p. 3). The Jamaican immigrants' reason for migrating to England seems to be a British dream, as Levy refers to her parents' aspirations: "They came to Britain on British Empire passports in order to find more opportunities for work and advancement" (Levy, 2014, p. 3). However, as the experience of Levy's parents indicate, the migrant's dream fails once they reach there: "In England, the fabled Mother Country that they had learned so much about at school in Jamaica, my parents were poor and working class" (Levy, 2014, p. 4). The Windrush migrants' experience further reveals the complexities and ironies of colonialism, the disappointment of the colonials who move to the centre of the empire, the "Mother Country". The migrants were expected to "assimilate and be as respectable as they possibly could" and "not make a fuss" (Levy, 2014, p. 4). Loss of language is another aspect of the migrant's deprivation. Levy's parents, for instance, had to conceal their Jamaican accent in England. They were made to be ashamed of their Jamaican culture and had to repress it. Levy says, "My mum was desperate for my dad to lose his accent” (Levy, 2014, p. 4).
The difficulties faced by the second-generation migrants can be observed in Levy's own experience. The conflict between the black and the British identities in the second-generation migrants and their identity crisis, as Şebnem Toplu reveals, "underscores the fact that second generation young black people are not accepted as British, despite the fact that they are born and raised in Britain" (Toplu, 2005, p. 4). Examining the "function of homeland and motherland for the translated hybrid identities" of the migrant in Levy's fiction, Toplu further accentuates Levy's optimism and argues that Levy's novel "provides a view of a new global hybrid identity and the future of multicultural Britishness" (Toplu, 2005, p. 12).

Levy's struggles as a second-generation migrant concerns being a stranger not only to herself and to her Caribbean heritage but also for the white, middle-class English. She mentions, for instance, her difficulty in being reconciled to the gap between her lower background of ethnicity and class and her English friends' middle-class origins at art college, where she first got acquainted with middle class people. Levy states that she had to hide from her friends the fact that she lived on a council estate. She narrates her memory of once being given a lift to her house by her friends and dropping at a "proper" house, feigning she lived there, in quite a Cinderellesque manner, saying "Keeping those origins of mine a secret became paramount. Few people at my college knew I lived on a council estate" (Levy, 2014, p. 6).

Levy connects the Caribbean immigrants' racial awareness and confrontation with racism with colonialism, as she thinks racism in the present dates from the racial apartheid associated with the British rule in the Caribbean (Levy, 2014, p. 4). Racial consciousness among Levy's family was also inherited from the colonial Caribbean in that the Levies isolated themselves from the darker skinned people (Levy, 2014, p. 5). Levy also dwells on the impact of racism on herself. She notes that she was ashamed of her Caribbean heritage and ignored it, because of the racism she was prone to. Racial prejudice also amounted to the feeling of self-hatred in Levy: "The racism I encountered was rarely violent, or extreme, but it was insidious and ever present and it had a profound effect on me. I hated myself. I was ashamed of my family, and embarrassed that they came from the Caribbean" (Levy, 2014, p. 5). Her status as a second generation immigrant, she says, led to her isolation and made her feel as an outsider. She reveals that she had to conceal her working class background and black heritage from her friends at college in the face of white, British, middle-class bias and pressure, as she says, "In my efforts to be as British as I could be, I was completely indifferent to Jamaica" (Levy, 2014, p. 5). She also notes she even wanted to apologise to the racist groups as she wanted to be acknowledged and respected in society. The racist attitude, she says, made her believe that her black heritage was "too foreign and therefore not worth knowing": Light-skinned or not, still we were asked, 'When are you going back to your own country?' (Levy, 2014, p. 5). 
Levy emphasizes the forgetfulness, ignorance and indifference of the British with regard to the history of the British Caribbean, involving slavery, colonialism and racial apartheid. Levy argues "The history of the black people of the Caribbean is missing" (Levy, 2014, p. 11) as she thinks "centuries of British slavery in the Caribbean" and its aftermath constitute "the absence, the gap in knowledge, the amnesia of the British that made the black man on the bus such an alien" (Levy, 2014, p. 9). Levy considers British mainstream history to be guilty, which she thinks, "underplayed" the significance of British plantation slavery in the Caribbean (Levy, 2014, p. 9). She states "That slave trade from West Africa to the Caribbean and the Americas was the largest forced migration in human history" (Levy, 2014, p. 8). For Levy, the British Empire grew as a result of slavery in the Caribbean. She further accentuates the irony of the post-slavery period in the British Caribbean in that Britain paid compensation to the slave owners rather than the slaves (Levy, 2014, p. 8). She further quotes Stuart Hall to account for her idea that the legacy and power of modern Britain owe to the British Caribbean, the Empire (Levy, 2014, p. 11-12).

Levy regards the post-slavery Caribbean society as "a social mix" including not only African slaves but also white immigrants, who escaped from Britain to begin a new and better life in the Caribbean, a majority of whom contained "press-ganged sailors, or convict labour", "Sephardic Jews from Iberia", "merchants from the Middle-East" and "indentured labourers from India and China" (Levy, 2014, p. 9). The heterogeneity of the Creole cultures forming the Caribbean was managed or controlled by the British, after the abolition of slavery, "through racial apartheid", by separating and thereby discriminating each culture to rule them better (Levy, 2014 , p. 9). Referring to the ignorance of both the white British and the Afro-Caribbean British concerning their common history and heritage, Levy highlights the need to acknowledge the shared history, the black-and -white legacy of Britain:

But there are still countless young Britons today of Afro-Caribbean descent who have as little understanding of their ancestry and have as little evidence of their worth as I did when I was growing up. And there are countless white Britons who are unaware of the histories that bind us together. Britain made the Caribbean that my parents came from. It provided the people-black and white-who make up my ancestry. In return, my ancestors, through their forced labour and their enterprise, contributed greatly to the development of modern Britain. My heritage is Britain's story too. It is time to put the Caribbean back where it belongs-in the main narrative of British history. (Levy, 2014, pp. 12-13)

\section{The Migrant Experience in "The Diary" and "That Polite Way That English People Have"}

"The Diary" is one of Levy's early stories. The inception of the story is related to Levy's dilemma concerning the period of her job as a dresser of ballet dancers, the memory of which she tried to "exorcise" by reading the story to the writing class she attended at the City Lit. Levy reveals that reading her story to others not only enabled her to avenge herself on her opponents because of her lack of opportunities but also made her aware of the power of humour as she thinks laughter renders her audience more willing to consider her perspective. Levy emphasizes it is not compensation for her past which pleases her so much as her ability to make her audience more susceptible to her views: "It was much more satisfying than the revenge. And once I'd made them laugh they seemed more open to what I had to say. I have never forgotten that." (Levy, 2014, p. 1)

The story is inspired by Levy's former disappointment due to her lack of proper employment despite her qualifications. The plot revolves around the story of a woman who is denied the opportunities suitable for her education and skills. The story is told in first-person. Working as an ironer of ballet dancers' tutus, the narrator repines at her miserable condition as she feels she deserves a career as a successful actress: "Me. Four years at college, a degree in drama, the talent to become a great actress, and I end up cross-eyed over an ironing board" (Levy, 2014, p. 1). She quits the job to fulfil her dreams regarding the theatre. Although her new job offers a very low payment, she accepts it for professional reasons, for the sake of the artistic and intellectual milieu it might provide. Her new job involves dressing actresses, sewing gussets into dresses to make them bigger and sewing labels into hats. However, the job frustrates her as she cannot benefit from the experience of working at a theatre as a company member to converse with the director, actors and actresses. She cannot even converse with the actor, who is her idol: "I did this for two weeks. Egalitarian? It was just one step away from slavery. The step being that I got to keep my own name. But the saddest thing of all was that I had made no impression on Paul Riceman" (Levy, 2014 , p. 4). The gap between the narrator's desires and her circumstances produces a comic and ironic effect, accentuating her underprivileged status as a black migrant; however, humour also helps the narrator to overcome her weakness and to gain power through ridicule of her circumstances:

But Zania said I'd get my name on the programme as a company member. I like the sound of that - a company member- it sounded egalitarian. I could see myself watching rehearsals, passing comments to the director, who'd pass them on to a grateful cast. Discussing Shakespeare and Pinter in the bar together - the actors, the director, me. An intellectual exercise. I took the job and Zania started me sewing gussets into trousers to make them two sizes bigger. (Levy, 2014, p. 2)

When the protagonist quits the second job, she realizes she has unknowingly picked someone else's diary, which happens to belong to Paul Riceman, her idol. As the covers of the narrator's book and the diary are of the same colour she mistakes it for her book, namely, Orwell's Down and out in Paris and London. The image of the interchange of books apparently having the 
same colour underlines the motif of cultural hybridity, shared history and multiculturalism as regards the intermingled histories and identities of the white and the black British. The colour image reinforces the issue of race. The mistaking of the diary of a white British actor for another white British male writer's memoir might symbolically suggest the overtones of cultural hybridity and the overlapping of the white and black, privileged and underprivileged, aspects of Britain in that the white actor's private life story concealed beneath a diary is interchangeable with the hybridity of Orwell's memoir. The allusion to Orwell's book highlights the squalor and destituteness of the migrant underworld. Orwell's book, being an autobiographical and historical memoir, examining the poverty in London and Paris, in the late 1920s, uncovers the repressed reality of hunger, starvation, unemployment, filth, and death beneath the splendour of the two European cities. Levy's autobiographical book parallels Orwell's memoir as it unravels the buried life of the "down and out" migrant in London, underneath the glamour of post-colonial Britain. The diary image might signify the repressed, dark, black unconscious of the white British self and the hybrid memory and history of Britain and its colonial and migrant others. The diary belonging to a white man in this story is appropriated or stolen by a black woman, which symbolically implies the appropriation of the rights and the identity of the white British by the black. By reversing the white hegemony by lowering the superiority of the white man, the actor, by making him subject to the black servant's, the sewer's power, Levy upsets racial hierarchy and demonstrates the interdependence and equality of black and white British. Levy divulges the convergence between the stories of the black outcasts of British society like the impoverished black woman narrator and the splendid performance of the white actors or rulers in this story. Possession of the knowledge concerning the secret life of the showy splendour of the actor, which empowers the narrator, might signify the secret, dark, repressed history of imperial Britain, which is symbolically disclosed and authorized by the black underlings such as the narrator. The diary image connects the personal diary with the social/historical memoir, blurring the borders between fact and fiction, autobiography and history, history and story.

The ambivalence of the diary which includes not only the white, brilliant story of the actor but his dark and hidden unknown stories as well, renders him vulnerable and the narrator's equal, as she realizes both his humanness and weaknesses but also her own power and potential as an actress whose talents equal her idol's. The narrator's recognition of Paul Riceman's personal story helps her to leave her cultural prejudice and gain self-confidence, as the diary contains the hybrid story of the white and the black British, the Caribbean and the English. The English actor's memory including his visit to the Caribbean makes the narrator his equal and enables her to gain the courage to apply for the job she aspires to as an artist to star with her white idol:

[...] He was everywhere. I thought I was going mad. But he looked as he always did: an Englishman full of charm and boyish humour, playing with his hair and flirting with the presenter. But if they knew about the afternoon of $21^{\text {st }}$ September, or that January in the Caribbean, they wouldn't sit so close to him.

It was then I decided to burn the diary. Make a bonfire out of it. [...]

But just as I was going to turn the television off, I heard him say he was looking for an actress, someone to star with him in his next film. [...] I didn't feel so small. It was the strangest sensation and I didn't know what it was. Then that voice said to me, 'You're an actress, and you've got a certain something.'

I picked up the phone and as I dialled the theatre and said, 'Paul Riceman, please,' I realised what the feeling was. It was power. (Levy, 2014, pp. 8-9)

"That Polite Way That English People Have" deals with the journey the Jamaican immigrants made to Britain. In this story, Levy is inspired by her mother's ship journey to Britain in 1948, six months after her father's arrival, and a story told by her. At the time Levy wrote this story, she was also in the early stages of writing her novel SMALL ISLAND, which concerned the immigration from Jamaica to Britain. The character Hortense would be a main character in her novel. The story was written to be read aloud and when Levy read it with a Jamaican accent, her mother was surprised and asked how she adopted the accent. Levy says, she told her mother that she owed her accent to her. However, her mother refuted her by saying she did not speak in that way. Levy reveals that her mother never lost her accent however hard she tried and denied (Levy, 2014, pp. 1-2).

The plot concerns a young Jamaican woman's immigration to England to train as a nurse. As the story is based on Levy's mother's migration to England six months after her father's voyage on the Windrush, there are semi-autobiographical aspects. Levy reveals through the first-person narrator's story, the difficulties and ironies of migration. The story emphasizes the migrant's journey, her desires to fulfil in England and the following disappointment. The narrator, Blossom/Hortense, for instance, emigrates to England to secure a good future there. However, her mother thinks she can attain the same goals in Jamaica and she further thinks her journey to England will cost her too much. She also informs her about the starvation in England after the war. But, Blossom sails to England without heeding her mother's advice. Blossom's account of her reasons for migration, her mother's opposition, and her struggle to realize her English dream is replete with the story of immigration, the romantic aspirations and the illusions of the migrant:

[...] But that wasn't why I was going to England. I was going to train as a nurse. Mamma said I could train as a nurse in Jamaica, that I did not have to go half way 
round the world to wear a fine starched uniform. But I told her I was going for better opportunity.

Mamma thought I was spending too much money on my passage. But I had worked hard for that money-from the age of sixteen I was a nanny to three English children. And I saved. (Levy, 2014, p.3)

The journey prefigures Blossom's disillusionment and hardship in England. Through the contrast of the weather, Levy stresses cultural difference. While it is so hot in Jamaica, Blossom will need a coat in England, which further emphasizes the ironies. She buys a coat from her white British employer, whose children she looks after for 10 years. The coat might symbolize the prosperous life aspired to by the Windrush immigrants for the coat stands for all the opportunities and dreams Blossom aims to fulfil through migration to England. It is evident that the coat functions as a means of achieving self-respect, self-fulfilment and social status for Blossom, the migrant, however it has an ironic consequence:

I WAS SURE MY coat would be the finest coat in England. Oh, everyone would stareeveryone would admire my long black coat and my black hat with its netting trim set at an angle on my head. There, they would say, there is high class woman from Jamaica. She is a woman who has one of the finest coats. (Levy, 2014, p. 1)

The words uttered to Blossom by the black man on the ship carrying her trunk can be regarded as a foreshadowing of her disillusionment in England due to racial prejudice (Levy, 2014: 4). Blossom does not heed his words as she thinks he is jealous of her opportunities: "That class of people are so jealous that the high class of us have a chance to better ourselves in England while they are left in the sun scratching out a living and waiting for the pumpkins to grow after the hurricane" (Levy, 2014, p. 5).

The hybridity of the narrator and her identity crisis can be seen in the scene where she gets acquainted with a white British man, whom she finds very handsome and refined. When the man, whom she refers as "this proper Englishman" (Levy, 2014, p. 6) asks her name she says "Hortense Hunter", her Christian name as she does not consider Blossom a suitable name in England. The scene is symbolic of the identity conflict and the change of identity experienced by the migrant:

He asked, 'May I ask your name?'

It was at that point, as he waited for my reply, that I decided Blossom was not a name to carry to England. Blossom was a name that was yelled from doorways in the hot sun. Women called Blossom fanned themselves with banana leaves and drank coconut milk straight from the nut. No, I decided I would use my real name. The name I was christened with- a name which would allow me to blend with tea time and croquet on the lawn.

'Hortense,' I told him, 'My name is Hortense Hunter.' (Levy, 2014, p. 7)

At the end of her journey as a migrant, Blossom/Hortense realizes painfully the ironic truth about England and the English. Neither the place nor the people are as she imagined. Through Joycean epiphany and irony, Levy demonstrates the futility of the migrant's desires, the image of darkness characterising the experience. Blossom's disillusionment, gazing into darkness when she arrives in England, highlights the ironies of migration. Levy further demonstrates the irony in a Maupassantesque conclusion, where Blossom not unlike Mathilde Loisel in Maupassant's "The Necklace", has an epiphany about deception. Like Mathilde who finally learns from her friend that the necklace was not original and that her long struggle to pay for the lost necklace that turned out to be only an imitation was for nothing (Maupassant, 1992, p. 37), Blossom learns from another Jamaican woman that she was deceived by her English employer in Jamaica from whom she bought her "fine" coat, which proves to be false and "ugly". All the money Blossom saved in Jamaica and all her struggle to realize her dream to come to England result in the ironic truth. Blossom's epiphany concerns her deception by the English and the irony of "that polite way that English people have" (Levy, 2014, p. 1):

By the time we got to England it was cold. [...] There was excitement all around the ship as we sailed into England. But it was very dark and I was a little disappointed that I could not make out Buckingham Palace or the Piccadily Circus as we manoeuvred into the dock. [...] And I carefully took out my coat. I said to myself, as I slid my arms into my warm garment and did up the buttons one by one, I am not one of those people who comes to England unprepared. "

$[\ldots]$ 'But this is an ugly coat' Petal whispered to me. So I told her that I had paid a great deal of money for this coat and that my employer had assured me that this was one of the finest quality coats money could buy. [...]

'Hortense,' she said, 'the English woman rob you. There is nothing fine about this coat.' (Levy, 2014, pp. 13-15)

Levy's "Afterword", which is a very short story entitled "February", powerfully depicts the challenges regarding migration as well as showing cultural difference and bias. The story, Levy says, is inspired by her mother, who, "has all the best stories" (Levy, 2014, p. 1). Similarly, the first-person narrator recollects an anecdote about her mother. The story concerns the essay her mother was assigned to write during the evening class she attended when she first came to England. Her mother, the narrator says, was expected to describe winter. However, as she wrote about winters in Jamaica, her essay was not approved by the 
instructor and she received a low grade. Levy depicts the ironies of migration and cultural prejudice through the opposition of Jamaican and British winters, the teacher's prejudice, the difficulty faced by the migrant mother and the ensuing failure of understanding between the British and the Jamaican, the resident and the migrant:

Now, not being very long in England, my mum was not that familiar with British winters. So she described the winters in Jamaica-her childhood Februaries. [...]

When my mum got this essay back from being marked she'd only got a $\mathrm{C}$ minus for all her effort. She was a little surprised. But then she read the reason written large in green ink.

'But this,' the teacher wrote, 'is not what February is like at all!' (Levy, 2014, p. 1)

\section{Conclusion}

Telling the long story of migration in its connections with the convergent stories of (post)colonialism, (post)slavery, racism, modernism and multiculturalism in her short narratives, Andrea Levy portrays both the advantages and the drawbacks of migration. Through her first-person narration and her reliance on humour, Levy forcefully reports, investigates and narrates the migrant experience, by focusing on the Caribbean migration to England and its relationship with the shared historical heritage of the Caribbean and Britain as well as her personal story. She exposes the challenges, conflicts, dualities and ironies concerning migration at the junction of autobiography, history and fiction. Levy's narratives further emphasize the necessity for redefining Britishness in multicultural Britain woven through the intermingled yarns of migration in "Back to My Own Country: An Essay" and her short stories "The Diary" and "That Polite Way That English People Have".

\section{REFERENCES}

Baxter, J. \& James, D. (2014). Introduction: towards serious work. In J. Baxter and D. James (Eds.), Andrea Levy: contemporary critical perspectives (18). London; NewYork: Bloomsbury Academic.

Duboin, C. (2011). Contested identities: migrant stories and liminal selves in Andrea Levy's "Small Island". Obsidian, 12 (1) (Spring/Summer), 14-33. Retrieved from https://www.jstor.org/stable/44489338

Ellis, D. (2001). "The Produce of More than One Country": Race, Identity, and Discourse in PostWindrush Britain. Journal of Narrative Theory, 31(2), 214-232. Retrieved January 7, 2020, from www.jstor.org/stable/30225763
Evelyn, K. (2013). Claiming a Space in the Thought-IKnew-You-Place: Migrant Domesticity, Diaspora, and Home in Andrea Levy's "Small Island". South Atlantic Review, 78(3/4), 129-149. Retrieved January $7, \quad 2020, \quad$ from www.jstor.org/stable/43739219

Gilroy, P. (1993). The Black Atlantic: modernity and double consciousness. Cambridge: Harvard University Press.

Hall, S. (2018). Familiar stranger: a life between two islands. London: Penguin Books.

James, C. (2010). "You'll Soon Get Used to Our Language" Language, Parody and West Indian Identity in Andrea Levy's "Small Island". Journal of West Indian Literature, 18(2), 45-64. Retrieved January 7, 2020, from www.jstor.org/stable/23019917

Levy, A. (2014). Six stories and an essay. London: Headline Publishing Group, eISBN $978 \quad 14722$ 22671 .

Levy, A. \& Fischer, S. A. (2014). Interview: Andrea Levy in conversation with Susan Alice Fischer (2005 and 2012). In J. Baxter and D. James. (Eds.), Andrea Levy: contemporary critical perspectives (121-138). London; New York: Bloomsbury Academic.

Maupassant, G. (1992). The Necklace and other short stories. Mineola; New York: Dover Publications, 3137.

Öztabak Avc1, E. (2018). Shifting "limits of tolerance and belonging" in Andrea Levy's fiction: an encounter with the refugee in "Loose Change". Manisa Celal Bayar Üniversitesi Sosyal Bilimler Dergisi, 16, 349366.

Toplu, Ş. (2005). Home(land) or 'motherland': translational identities in Andrea Levy's Fruit of the Lemon. Anthurium: A Caribbean Studies Journal. 3(1)7, 1-15. Retrieved November 14, 2019 from http://scholarlyrepository.miami.edu/anthurium/v $\mathrm{ol} 3 /$ iss $1 / 7$ 